\title{
Klimatická změna - široké, stále aktuální téma
}

\section{Jiří Nečas}

\section{Envigogika 11 (1) - Inspirace/Inspiration}

Publikováno/Published dne 28.4.2016

DOI: $\underline{10.14712 / 18023061.519}$

\begin{abstract}
Abstrakt
Jak je tomu se současnou klimatickou změnou? Použijme příklad z medicíny. Rakovinou plic mohou onemocnět i nekuřáci. Pokud je kuřákovi tato nemoc indikována, bylo by zcela absurdní, kdyby argumentoval jejím výskytem u nekuřáků a odmítal jako součást léčby přestat kouřit. My známe velmi pravděpodobnou přičinu současných klimatických změn a bylo by absurdní tvrdit, že probíhají nezávisle na lidské činnosti, a nesnažit se omezit faktory, které je podporují.
\end{abstract}

\section{Klíčová slova}

Klimatická změna; encyklika Laudato si'; konference COP21.

\section{Abstract}

How are things these days with climate change? Let's use a medical metaphor. Nonsmokers can contract lung cancer. If this disease is indicated for smokers, it would be absurd to argue its prevalence in non-smokers and, as part of the treatment, to reject the importance of stopping smoking. We know the most probable cause of current climate change and it would be equally absurd to claim that the changes are occurring independently of human activity while not trying to reduce the factors that exacerbate these changes.

\section{Keywords}

Climate change; encyclical Laudato si'; conference COP21. 
Prosincová pařížská klimatická konference potvrdila, že téma klimatická změna nepřipravila o význam či aktuálnost ani taková díla jako "Skeptický ekolog" B. Lomborga (2006) či "Modrá, nikoli zelená planeta" V. Klause (2007). A i když existuje široký konsensus v tom, že klimatická změna ("globální oteplování") probíhá a lidský podíl na ní je nezanedbatelný, nezanedbatelný je i počet "klimaskeptikư", kteří s tímto konsensem nesouhlasí. Můžeme je rozdělit do dvou skupin ${ }^{1}$. Do první patří ti, kteří bud' aktuální proces změny klimatu jako takový neuznávají, nebo odmítají o něm mluvit s poukázáním na to, že k podobným tvrzením zatím chybí dostatečný časový odstup. Druhou skupinu tvoří ti, kteří sice existenci klimatické změny nepopírají, avšak tvrdí, že klima se měnilo i v minulosti, v dobách, kdy člověk na zemi ještě nežil, a o toto tvrzení opírají své odmítání či banalizování lidského podílu na měnícím se klimatu.

Aniž bych klimaskeptikum upíral svobodu jejich názoru, jsem přesvědčen, že se hluboce - a zároveň nebezpečně - mýlí. Data dokumentující trend ve vývoji klimatu na planetě Zemi existují. Bylo by zajímavé moci je vyhodnotit $s$ větším časovým odstupem, jenže zde jde o data alarmující, vyzývající k okamžité akci, a tak pasívně čekat na pohled z větší dálky by bylo nemoudré a nemorální, a mohlo by být až sebevražedné.

Nepochybuji o tom, že se mýlí i ti, kdo patři do druhé skupiny klimaskeptiků. Je pravda, že se klima $v$ dějinách planety Země mnohokrát měnilo i před člověkem. Mění se $\mathrm{i}$ nyní. Máme $\mathrm{k}$ dispozici modely, které zhruba a s velkým časovým odstupem vysvětlují dlouhodobé historické klimatické změny, at' už vlivem vnějších faktorů, nebo některými procesy probíhajícími na Zemi, zpravidla vyvolanými vnějšími faktory někdy $v$ minulosti. Naši klimaskeptici z toho (často asi demagogicky) usuzují, že změny klimatu obecně jsou jevem nezávislým na člověku.

Mnohé příčiny zmíněných neantropogenních změn klimatu známe, některé (zatím ?) nikoli. Jak je tomu však se současnou klimatickou změnou? Její vysvětlení lidskou činností se doslova nabízí. Jde především o růst koncentrace skleníkového oxidu uhličitého $v$ atmosféře $v$ průběhu industriální éry, o meteorologické jevy, které Ize vysvětlit ubýváním deštných pralesů atd. Naše současné poznání neumožňuje přesnou kvantifikaci podílu lidské činnosti na měnícím se klimatu. Použijme příklad z medicíny. Rakovinou plic mohou onemocnět i nekuřáci. Pokud je kurákovi tato nemoc indikována, bylo by zcela absurdní, kdyby argumentoval jejím výskytem u nekuřáků a odmítal jako součást léčby přestat kouřit. My známe velmi pravděpodobnou příčinu současných klimatických změn a bylo by absurdní tvrdit, že probíhají nezávisle na lidské činnosti a nesnažit se omezit faktory, které je podporují.

Dále tedy přijmeme přirozený předpoklad, že se člověk na příčinách změn klimatu výrazně podílí. To přirozeně budí otázku, zda Ize tento proces zastavit či zvrátit. Asi na ni Ize odpovědět „šalamounsky”, že zčásti ano, úplně nikoli, avšak nejsme s to říci, o jak velkou část jde. Naše poznání Země na to zatím nestačí. Rozhodně aktuální situace je výzvou ke změně současné praxe využívání zemského bohatství, k daleko šetrnějšímu zacházení s planetou Zemí. Cíl pařížské konference nežádoucí proces změny klimatu zpomalit (či zastavit?) tak, aby roku 2100 globální teplota zemského povrchu nepřevyšovala tuto teplotu z předindustriální sféry o více než $1,5{ }^{\circ} \mathrm{C}$, je sice velmi ambiciózní, avšak svým způsobem budí pochybnosti o serióznosti: Můžeme vynaložit veliké úsilí (a je to naší morální a pravděpodobně i existenciální povinností), avšak pány Země nejsme. Větru, dešti

\footnotetext{
${ }^{1}$ Je možné, že pro některé klimaskeptiky je hlavním motivem jejich postoje snaha stát mimo "main-
} stream". 
sice poroučeli komunističtí budovatelé z padesátých let, ale víme, že o jejich slovech vždy bylo možno s úspěchem pochybovat. Závazky týkající se množství emisí skleníkových plynů, plochy deštných pralesů apod. by byly daleko konkrétnější a serióznější. Nicméně samu skutečnost, že $k$ určité dohodě $v$ Paříži došlo a že byl určitý cíl vytyčen, je možno považovat za úžasný úspěch a za "etapové" vítězství odpovědnosti a zdravého rozumu.

Pařížská konference se konala půl roku po vydání "přelomové" encykliky papeže Františka "o péči o společný domov" Laudato si'. Encyklika je zřetelným vyjádřením toho, že péče a angažovanost pro planetu Zemi je úkolem všech lidí. Prosincová konference potvrdila, že vývoj klimatu, tedy jedné velmi důležité složky systému naší planety, se týká všech a je třeba se $v$ jeho prospěch angažovat. Konsensu bylo dosaženo. Avšak jak se promítne do reality $v$ jednotlivých státech? Jako občan ČR a tím i Evropské Unie se ptám, jak závěry konference ovlivní život $v$ našem státě, jak v EU. A s určitými rozpaky si uvědomuji, že jsem $v$ předchozí větě možná místo tázacího př́slovce jak měl použít príslovce zda. Záhy po skončení konference se u nás opět mluvilo o prolamování těžebních limitů, o přípravě a stavbě nové přistávací dráhy, která by umožnila zvýšení provozu na pražském Letišti Václava Havla a o dalších záměrech, které by plnění pařižského závazku nepodporovaly. Myslíme tedy onen závazek vážně nebo jen počítáme, nejen kolik vlád, nýbrž dokonce kolik lidských generací v produktivním věku se vystřídá do roku 2100 , k němuž je směřován?

V Paříži se účastníci shodli na tom, že je třeba něco dělat. Není tato přelomová skutečnost, navíc v kombinaci s Františkovou loňskou encyklikou, opravdovou výzvou ke změně? $\mathrm{K}$ intenzívnímu rozvoji nefosilní energetiky. $\mathrm{K}$ omezování dopravy, pro něž vysoce rozvinutá a stále se dynamicky rozvíjející informatika nabízí skvělé možnosti. $\mathrm{K}$ všeobecnému šetření hmotnými statky a důrazem na statky duchovní. Atd. Jistě, neobejde se to bez změny ekonomických paradigmat. I na tom je třeba pracovat a přestat konečně $s$ kultem neoliberální ekonomie, která snad byla dobrá pro potenciálně neomezený svět, avšak nehodí se pro pohyb v okolí hranic možností. Otvírá se zde široké pole pro výzkumníky, pro pedagogy, novináře, spisovatele, kněze a kazatele. Vítězství kooperace nad konkurencí v mezinárodním měřítku by se mohlo a mělo promítat do podobného vítězství kooperace nad konkurencí na nejrozmanitějších nižších úrovních. Planeta Země je náš společný domov. Péče o ni je společným, krásným a důležitým úkolem všech lidí.

\section{Literatura}

- Laudato si' (Encyklika papeže Františka o péči o společný domov). Praha, Paulínky 2015.

- Klaus, V.: Modrá, nikoli zelená planeta. Praha, Dokořán 2007.

- Lomborg. B.: Skeptický ekolog. Praha, Dokořán - Liberální institut 2006. 